\title{
Kunsten at lære at mobbe - et studie af mobning som kulturelle læreprocesser
}

\author{
Mille Mortensen, Peter Hagedorn-Rasmussen \& Rikke Thomsen
}

Denne artikel undersøger, hvilken rolle arbejdspladskultur spiller for tilblivelsen af mobning på arbejdspladsen. Artiklen udforsker og tilbyder en ny tilgang til at belyse, hvordan mobning opstår på arbejdspladsen. Med et etnografisk afsæt præsenteres en læringsorienteret forståelse af, hvad arbejdspladskultur er (Hasse, 2011), hvordan det opstår, samt hvordan det er under stadig tilblivelse og forandring. Denne forståelse komplementerer den eksisterende mobningsforskning og udfordrer et overvejende triadisk perspektiv på mobning som fænomen. Artiklen er funderet på førsteforfatters etnografiske feltarbejde inden for hospitalsverdenen. Betydningen af arbejdspladskulturens rolle for mobning, er vokset frem gennem empirien og bliver tydelig via analysen. På den baggrund bidrager artiklen dels med at vise arbejdspladskulturs fundamentale rolle for mobning, og dels med at åbne for nye måder at forstå den dynamiske tilblivelse af fænomenet. Denne tilgang til mobning som fænomen har potentielt vidtrækkende konsekvenser for fremtidige håndterings- og forebyggelsesstrategier, idet forskningen har haft et overvejende individorienteret fokus på rollerne som mobber, offer og vidne, frem for et arbejdspladskulturelt perspektiv.

Nøgleord: mobning, krænkende handlinger, arbejdspladskultur

\section{Indledning}

Mobning på arbejdspladsen er et alvorligt og mere omfattende problem, end mange umiddelbart antager. Det Nationale Forskningscenter for Arbejdsmiljø (2018, s.31) har for eksempel dokumenteret, at 10,7\% af danskerne rapporterer, at de har oplevet sig udsat for mobning på arbejdspladsen inden for de sidste 12 måneder. Den internationale forskning $\mathrm{i}$ mobning på arbejdspladsen (Einarsen, Hoel, Zapf \& Cooper, 2011) er karakteriseret ved en udbredt enighed om, at mobning defineres som vedvarende og systematiske krænkende handlinger, der medfører, at ofret ender i en inferiør position i form af eksklusion fra arbejdsfællesskabet (ibid., s. 22). De krænkende handlinger kan være personrettede, som $\mathrm{fx}$ etnicitet, køn eller seksuel orientering, arbejdsrettede, som fx kompetencer, tempo eller kvalitet, og endelig kan de have en seksuel karakter i form af uønsket seksuel opmærksomhed (ibid., s. 13). Yderligere baseres forskningen på antagelser om, at mobning opstår enten på grund af eskalerede interpersonelle konflikter på arbejdspladsen (D'Cruz, 2015; Mikkelsen, Hogh \& Puggaard, 2011) eller er forårsaget af mobberens dysfunktionelle personlighed, der forårsager de krænkende 
handlinger (Fox \& Freeman, 2011; Linton \& Power, 2013; Mathisen, Einarsen \& Mykletun, 2011; Pilch \& Tuska, 2015). Det antages i en stor del af forskningen, at det er muligt og meningsfuldt at fremstille en stabil og entydig problemidentifikation, hvor der eksisterer klare modsætningsforhold mellem aktørerne, der er indskrevet i veldefinerede roller som mobber, offer og vidne. Med et intrapsykisk og interpersonelt perspektiv på mobning, individualiseres forståelsen og forklaringen på mobning. Et begrænset antal kvalitative studier har undersøgt, hvordan ansatte kan opleve ledelsers og medarbejders udøvelse af undertrykkende organisatoriske (økonomiske og effektiviserings-) regimer som mobning (D'Cruz, 2015; D'Cruz \& Noronha, 2013; Liefooghe \& Davey, 2001). D'Cruz og hendes kolleger konstruerer begrebet 'de-personalized bullying' til at beskrive et socio-strukturelt og institutionaliseret mobningsfænomen. Herudover har vi set, hvordan fx den tidligere forskning i Danmark, har været åben overfor, at mobning også er processuel (Einarsen \& Gemzøe, 2000, s. 22). De metodiske, og delvist teoretiske, tilgange har dog ikke givet anledning til at udforske mobning ud fra en arbejdspladskulturel tilgang.

Artiklen supplerer denne forskning med et arbejdspladskulturelt perspektiv på tilblivelse af mobning. I den sammenhæng viser et læreprocesperspektiv sig at være centralt. I artiklen trækker vi på antropologen Cathrine Hasses (2011) kulturbegreb, hvor også begrebet tankeredskaber (2011, s. 75) kommer fra. Tankeredskaber organiseres gennem kulturelle modeller, "... hvor artefakters betydning bygges ind i selvfølgelige og forventelige relationer og forløb." (ibid., 2011, s. 97), som hjælper os til at få øje på nye aspekter af et fænomen. I forskning, er teorier og begreber væsentlige tankeredskaber. Men de bliver også - særligt i anvendelsesorienterede forskningsgrene tankeredskaber, som rækker ind i praksis. Om mobning primært tænkes som individuelt, interpersonelt eller arbejdspladskulturelt fænomen har afgørende betydning for, hvilke opmærksomhedsfelter og handlerum, der åbner sig i såvel forskning som i praksis.

I det følgende afsnit sætter vi yderligere fokus på mobning i et arbejdspladskulturelt perspektiv. I den sammenhæng tydeliggøres artiklens forskningsspørgsmål, og vi præsenterer centrale og relevante kulturteoretiske begreber for analysen af mobnings tilblivelse. Herefter præsenteres artiklens empiriske og metodiske grundlag, som desuden udgør overgangen til den egentlige analyse. Analysen udfolder de processuelle og flertydige karakteristika ved arbejdspladskulturens stadige tilblivelse og viser, hvordan denne udspiller sig gennem læreprocesser, der giver grundlag for 'mestring' af 'mobning'. Artiklen afrundes med en konklusion og perspektivering.

\section{Kulturelle perspektiver på mobning i arbejdslivet}

Samspillet mellem kultur og mobning i arbejdslivet belyses i en række forskellige studier. Pheko, Monteiro og Segopolo (2017) samt Trépanier m.fl. (2016) ser på, hvordan organisationskultur kan have afgørende direkte eller indirekte betydning for, hvorvidt mobning opstår på arbejdspladsen. Disse bidrag er kendetegnet ved at have en primært konceptuel og teoretisk karakter, der umiddelbart ikke giver mulighed for at se ind i de dynamikker, som skaber grundlaget for mobning på arbejdspladsen. Den internationale forskning har gennem flere kvantitative undersøgelser (An \& Kang, 2016; Einarsen \& Raknes, 1997; Keashly \& Jagatic, 2011; Pilch \& Tuska, 2015) desuden kunne sandsynliggøre en sammenhæng mellem typer af normer og organisationskultur og mobning. Bloisi og Hoel (2008) viser i deres litteraturstudie af undersøgelser i restaurationsbranchen, hvordan mobning opstår og vedligeholdes gennem uddannelse, træning og socialise- 
ring af de ansatte i branchen. Ligeledes viser Hoel og hans kolleger (2007), ved hjælp af fokusgruppeinterview med sygeplejersker under uddannelse, hvordan de oplevede sig udnyttet, ignoreret og uvelkomne i deres praktikforløb, uden at beskrive deres oplevelser som mobning. Forskerne konkluderer, at hvis de sygeplejerskestuderende reagerer på deres oplevelser ved at undertrykke deres følelser og udvikle en hårdhed, kan denne adfærd i sig selv medføre en reproduktion og dermed legitimering af selvsamme mobbeadfærd. Ligeledes konkluderer Keashly og Jagatic (2011, s. 60), at de normer og værdier, som fjendtlig adfærd bygger på, formentlig og ofte er konsistente med dem som organisationskulturen bygger på.

I en dansk kontekst har Bloch (2012) ved hjælp af interviews undersøgt, hvordan mobbere opfatter og forklarer deres krænkende handlinger rettet mod kolleger. Hun viser, hvordan mobberne betragter ofrene som normbrydere, hvilket legitimerer mobningen i krænkernes perspektiv. I undersøgelsens konklusioner beskriver hun, hvordan mobberne og ofrene trækker på forskellige moralske aspekter af arbejdssituationen: Mobberne legitimerer deres krænkende handlinger i relation til gruppens normer, hvorimod ofrene relaterer deres handlinger i relation til de sårbare livsomstændigheder, de hver især befinder sig i (ibid. s. 174).

\section{At forstå mobningens tilblivelse som socialt foenomen}

Artiklen her komplementerer disse bidrag gennem det etnografiske studies særlige blik for at udforske og belyse, hvordan arbejdspladskulturelle normer og værdier, der fordrer og/eller understøtter mobning, opstår, reproduceres og/eller forandres i praksis. Det muliggør et forståelsesorienteret perspektiv på arbejdspladskulturens konkrete betydning for mobningens opståen og ikke mindst den fort- løbende tilblivelse gennem socialiserings- og læringsprocesser. I den forbindelse har det været givtigt at lade sig inspirere af mobningsforskning inden for folkeskoleområdet. I projektet 'Exploring bullying in school', Exbus, har Schott (2009), som medlem af en større dansk forskningsgruppe, undersøgt mobning, ved brug af kvantitative såvel som kvalitative metoder. Schott har på baggrund heraf formuleret en alternativ definition af mobning som et "...socialt foenomen snarere end som en relation mellem individuelle mobbere og deres ofre." (ibid., s. 225). I udformningen af definitionen betoner Schott, hvordan alle formelle institutioner som fx en skole eller en arbejdsplads kontinuerligt producerer uformelle grupper gennem in- og eksklusionsmekanismer. Det er med til at skabe mobningens sociale kontekst (Schott, 2009, s. 249). Risiko for mobning øges, når angst for at blive ekskluderet fra gruppen får selvsamme til at projicere truslen over på bestemte gruppemedlemmer. Kofoed og Søndergaard (2009), der ligeledes arbejder inden for en skolekontekst, argumenterer i forlængelse heraf for nødvendigheden af, at forskningen skifter fra et individ- og personlighedstræks-fokuseret perspektiv til at forstå mobning som et resultat af sociokulturelle dynamikker, skabt i samspil mellem mange forskellige kræfter, der sammen skaber pres på og i et fællesskab. Sådanne dynamikker kan vi først få øje på, når vi i stedet for at stille spørgsmålet: 'Hvem er den/de skyldige, og hvad er der galt med ham/hende/dem?' stiller spørgsmålet: 'Hvad er det $i$ vores kulturelle praksisser, som gør det oplagt og/eller nødvendigt for ham/hende/dem at gøre det, han/hun/de gør?' Førsteforfatter har i forlængelse heraf identificeret et 'fluktueret mobningsfoenomen' i en arbejdslivskontekst, karakteriseret ved, at positionerne som mobber og offer vedvarende skifter i arbejdsfællesskabet. Det betyder samtidig at positionen som vidne udgrænses (Mortensen \& Baarts, 2018). De 
ansatte beskriver, hvordan de befinder sig i en 'double bind' position (Bateson, 1972), hvor de oplever sig nødsaget til at lade sig udsætte for samt selv udøve, hvad de betegner som nedgørende og dermed grænseoverskridende adfærd, for at opnå accept af samt højne egen sociale status i arbejdsfællesskaber. Ved at afstå fra deltagelse i mobningen oplever medarbejdere nemlig, at risikere at blive ekskluderet fra fællesskabet, hvilket besværliggør - eller i værste tilfælde afskærer dem fra - at kunne varetage deres arbejdsopgaver (Mortensen \& Baarts, 2018). Der synes samtidig at være en flydende grænse mellem det, der er bevæggrundene for deres adfærd og så de uintenderede og uhensigtsmæssige konsekvenser heraf, nemlig mobning. Det er med afsæt i disse perspektiver, at nærværende artikel undersøger, hvilken rolle arbejdspladskultur spiller for tilblivelsen af mobning på arbejdspladsen? Formålet er at tilvejebringe indsigt $\mathrm{i}$, hvordan in- og eksklusionsmekanismer, og dermed grundlag for mobning, konkret opererer gennem arbejdspladskulturelle praksisser.

\section{Kultur som kropslige lareprocesser}

Vi har valgt at tage afsæt i kulturpsykologien (Cole, 1996; Hasse, 2011). Med den forstår vi kultur som "...loereprocesser, der skaber forbindelser (...) der skaber relationerne mellem materialitet og betydning og handlinger og betydning." (Hasse, 2011, s. 16). Hasse trækker på en lang række teoretikere. Af relevans for vores tilgang kan bl.a. nævnes den kulturhistoriske skole omkring Vygotsky (Vygotsky \& Cole, 1978), Bateson (1972) fokus på forskelssætning, og læringsperspektiver fra bl.a. Lave og Wenger (1991), pragmatisme (Dewey, 1916/66) og praksisteorien (Gherardi, 2000). Tilgangen adskiller sig fra en række af de tidligere nævnte studier, som har haft fokus på organisationskulturens betydning for mobning, særligt knyttet til fx Edgar Schein (1984). Rammerne for artiklen muliggør ikke en nærmere redegørelse for dette, hvorfor der i øvrigt henvises til fx Hasse (2011, kap. 2; Schultz, 1990) for en nærmere belysning af forskellene.

Afsættet er, at kultur ikke er noget, vi har i organisationer, men noget vi gør, når vi lærer i en konkret praksis, der forbinder vores viden og handling. Kulturelle praksisser skabes dér, hvor mennesker mødes og gennem (sprog) handlinger skaber forbindelser, dvs. kognitive forankrede betydninger og meninger i relationer, mellem geometriske, dvs. fysiske/ virtuelle, og sociale rum. På arbejdspladsen orienterer deltagerne sig i rummet, og agerer $\mathrm{fx}$ anderledes i møderummet end i kantinen. Deltagerne bruger forskellige tiltaleformer og jargon afhængig af, om de taler med kolleger, chefer eller borgere/patienter. Læring og kultur spiller sammen: "Vi loerer med hele kroppen og alle dens sanser." (Hasse, 2011, s. 29). Den menneskelige aktivitet medieres i den forbindelse af forskellige artefakter, som tegn og redskaber. Teorier og modeller er eksempler på tankeredskaber, der medierer vores forståelse af sociale verdener (ibid., s. 76). Men også redskaber som stole, kirurgiske redskaber, rum mv. kan optræde som artefakter, der får deltagere til at rette deres opmærksomhed særlige steder hen. Læring i samspillet med disse redskaber transformerer deltagerne, men også løbende deres indbyrdes relationer. Det kirurgiske redskab i hånden på en novice optræder som et fremmed instrument, hvorimod instrumentet i hånden på en erfaren kirurg opleves, som en forlængelse af kroppen, der hjælper kirurgen til at rette opmærksomheden på det sted, hvor kniven skal gøre sin virkning (se også Gherardi, 2000; Hasse, 2011, s.161-2). De forskellige deltagere i operationsteamet orienterer sig forskelligt og trækker på forskellige artefakter og tankeredskaber samtidig med, at de også fungerer som et fællesskab.

I organiserede fællesskaber udvikles og reproduceres bestemte forbindelser, imens 
andre udgrænses, hvorigennem kulturelle grænser opstår. Forbindelserne skaber over tid forventninger til en specifik adfærd, der, når den bekræftes, bliver til kollektive kulturelle selvfølgeligheder (Hasse, 2011, s.16). Dét, den kulturelle novice (herunder forskeren) "... skal loere, er ikke kognitive forbindelser, men handleviden $i$ det empiriske felt. (...) Kulturelle novicer, der ikke loerer at loese disse klynger af kulturelle forbindelser, der giver handleviden, risikerer eksklusion..." (ibid., 2011, s. 31). En eksklusion som vanskeliggør, hvis ikke den forhindrer, det enkelte organisationsmedlem $i$ at udføre sit arbejde. Den kulturelle ekspert, opstår således, når den erfarne mestrer evnen til at læse handlemuligheder og begrænsninger i arbejdsfællesskabers sociale rum. I forhold til arbejdspladskultur rækker handleviden ind $i$ at kunne mestre fx en særlig omgangsform, jargon, humor, hilseformer, korrekt placering i rummet til en morgenkonference, hvis det er en kulturelt indlejret norm. Beherskelsen af sådanne kulturelle markører har betydning for, hvordan deltagerne positioneres i det kulturelle fællesskab (ibid., 2011, s. 127-8). Kultur er

"...dette indviklede netvoerk af forbindelser, der in- og ekskluderer mennesker, genstandsartefakter og ord i organisationer." (Hasse, 2011, s. 17).

Denne fælles kollektive betydningsdannelse, der opstår over tid, lærer deltagerne, "... at rette vores opmoerksomhed mod samme objekt og tilloegge objektet samme betydning." (ibid., 2011, s. 86). Med andre ord - vores opmærksomhedsfelt antager bestemte former.

Kulturelle selvfølgeligheder praktiseres af organisationsmedlemmer som tavs, kropslig og automatiseret adfærd. Sådanne er vi ofte ikke opmærksomme på, førend vi enten bliver forhindret $i$ at udføre vores praksis, eller at nogen eller noget præsenterer nye mulige forbindelser i relationerne mellem handling og betydning. Det sker fx ved at gøre eller sige noget andet end det, fællesskabet plejer at gøre - dets sædvaner. Det skaber friktion, som gør, at vi pludselig bliver bevidst om noget, der har været taget for givet.

Organisation eksisterer således ikke som én sammenhængende homogen kultur. Organisationer - eller mere præcist formuleret ved brug af udsagnsordet organiseringer, som betoner praksisserne - må i stedet forstås som 'distribueret' (Hasse, 2011, s. 54). Organisering er stadige tilblivelser af samlinger, som består af fragmenter fra sociale og geometriske rum. Her skabes midlertidige kulturelt selvfølgelige praksisser, der vedvarende transformeres, uden begyndelse eller slutning, via friktioner (Hasse, 2014, s. 20), der finder sted som forskellige organisatoriske omstillinger som $\mathrm{fx}$ indførsel af ny teknologi, udskiftning af ledere eller medarbejdere eller nye arbejdsgange.

\section{Kulturelle markører og kunsten at loere at mobbe}

Som beskrevet først i denne artikel, defineres mobning netop ved vedvarende og systematiske krænkende handlinger, der fører til én eller flere organisationsmedlemmers eksklusion fra (arbejds)foellesskaber. Det vil sige, at den deltager, der mestrer fællesskabets kulturelle markører, øger sine chancer for at blive vurderet værdig til medlemskab og dermed inklusion, fordi vedkommende genkendes gennem social udpegning af fællesskabets øvrige medlemmer. 'Social udpegning' er

"...den konkrete proces, hvorigennem deltagere i organisationens hverdagsliv fär udpeget, hvilken betydning de fysiske artefakter (herunder menneskers kropstegn og handlinger) tilloegges af de mere erfarende deltagere i organisationen." (Hasse, 2011, s. 152).

Med andre ord bliver vi som organisationsmedlemmer til gennem kulturelle lærepro- 
cesser i arbejdsfællesskaber: "Organisationskultur skaber, transformerer, nedbryder og in- og ekskluderer tilblivelser." (Hasse, 2011, s. 148).

Som vi skal se i analysen tilbydes de fagprofessionelle - og i dette forskningsprojekt også etnografen - at lære at mestre kulturelle markører, der omtales som 'en hård tone'. I denne læreproces gives den fagprofessionelle mulighed for at blive socialt udpeget som værende hårdfør nok til at blive accepteret og inkluderet i arbejdsfællesskabet på hospitalet. Sådanne kulturelle læreprocesser kan have en flertydig og ambivalent, eller endog paradoksal natur. I et praksisfællesskab møder den kulturelle novice de formelle regler og det formaliserede jobdesign, men også alle de situerede og tavse praksisformer, der vanskeligt lader sig italesætte, og som i mange tilfælde adskiller sig fra det formaliserede og rationaliserede strukturelle og kulturelle organisatoriske design. Og her gælder det, at læreprocesser både kan inkludere det, som påskønnes fagprofessionelt og sanktioneres organisatorisk, men også de sædvaner og praksisser, der kan kompromittere såvel det 'rationelle' design som almindelig sund fornuft. Humor på arbejdspladsen er fx et avanceret fænomen, som kan fremtræde krænkende og antage form af mobning (Mortensen \& Baarts, 2018). Mobning og humor kan i den forbindelse forstås funktionelt (Mortensen \& Mygind du Plessis, 2019), dvs. mobning som praksis tjener andre arbejdslivsbetingede funktioner end blot, at (nogle) mennesker ynder at opføre sig ondskabsfuldt over for andre. I tilfældet for læger og sygeplejersker viser analysen (ibid.), at den nedgørende og krænkende humor benyttes til at håndtere et krydspres mellem et krav om et effektivt arbejdsliv og et ideal om perfektion $i$ arbejdet.

Med afsæt i det arbejdspladskulturelle perspektiv som tankeredskab, bevæger vi os ind i det empiriske felt for at udforske, hvordan mobning som fænomen opstår som uhensigtsmæssige konsekvenser af tavse, selv- følgelige og indlejrede kulturelle praksisser i arbejdsliv. Det er med begreber som 'loering gennem forbindelser mellem deltagere', 'afkodning af kulturelle markører', 'handleviden' og 'social udpegning', der skaber 'positioner', vi åbner op for at udforske, hvilken rolle arbejdspladskultur spiller for tilblivelsen af mobning som en kulturel selvfølgelighed på arbejdspladsen som et alternativt tankeredskab. I første omgang præsenteres den empiriske og metodiske baggrund, hvorefter den egentlige analyse udfoldes.

\section{Ind i mobningens praksis - forskningsprojektets empiriske og metodiske baggrund}

I 2011 gennemførte Rigshospitalet en trivselsmåling, der viste udfordringer med oplevet mobning blandt de ansatte. Undersøgelsen viste en stor variation, på tværs af afdelingerne, i andelen af ansatte, som havde oplevet sig udsat for mobning. Ledelsen oplevede sig sat skakmat i håndteringen og forebyggelsen af den mobning, der fremgik af undersøgelsen. På den baggrund indgik førsteforfatter til artiklen her, som vi efterfølgende refererer til som etnografen eller forskeren, en aftale med hospitalets ledelse, om at iværksætte et PhD-forskningsprojekt med det formål at undersøge, hvordan og hvorfor mobning kan opstå i arbejdsliv.

Med ønsket om at skabe vej ind $i$ mobningens praksis, faldt valget på at udføre et etnografisk feltarbejde. Det etnografiske metodiske greb giver forskeren mulighed for at studere og undersøge fænomener in situ, hvilket frembringer et 'rigt', detaljeret og nuanceret indblik i menneskers levede (arbejds-) liv (Geertz, 1973). Hermed skabes mulighed for at producere viden om den kompleksitet, omskiftelighed, hastighed, mangfoldighed og ubestemmelighed, som felten (det empiriske objekt) og dens medlemmer lever i og med i relation til feltet (det analytiske objekt) (Hastrup, 2003). 
Etnografien giver mulighed for at trænge dybere ind i forståelsen af de kulturelle dynamikker og forbindelserne mellem de kulturelle markører. Det etnografiske feltarbejde er ikke blot fordelagtigt at anvende, men en egentlig nødvendighed, når forskere ønsker at studere og analysere "...de kropsligt positionerede og kulturelle loereprocesser i fysiske rum..." (Hasse, 2011, s. 13) fx i arbejdsliv. Forståelsen bunder i antagelsen om, at "...verden ikke kan observeres. Den skal erfares." (ibid.). Det betyder, at etnografien bygger på en antagelsen om, at "vores erfaringer af en omverden har kroppen i centrum (...) og at det er en loerende krop." (ibid.). Kulturelle praksisser udfolder sig dér, hvor etnografen skaber forbindelser, betydning og mening i relationer med aktørerne i felten og i de geometriske rum, disse fungerer i. Etnografen bliver nemlig, ligesom organisationsmedlemmerne, til gennem praktisering af kulturelle læreprocesser og får herved mulighed for at undersøge, hvem etnografen kan blive til, i den konkrete organisatoriske praksis. Ét for etnografen lærerigt feltarbejde i det konkrete forskningsprojekt ville med andre ord være, at blive udsat for og måske endda selv udøve krænkende handlinger og mobning.

Etnografen gennemførte deltagerobservation blandt læger og sygeplejersker i fem måneder via dag-, aften-, weekend- og nattevagter på Rigshospitalet svarende til et fuldtidsjob. Herigennem bestræbte forskeren sig vedva- rende på at placere og dermed kontekstualisere konkrete menneskers og materialiseringers møder i sociale og geometriske rum i en meningsfuld sammenhæng. Det genererede empiriske materiale, til brug for senere analyser, blev dokumenteret gennem nedskrevne narrative feltnoter. Disse omhandlede det observerede, det som var blevet fortalt dagligt og som etnografen oplevede (Jackson, 1990). Feltarbejdet blev planlagt i samarbejde med den øverste ledelse, de klinikledelser og afdelingsledelser, hvor det efterfølgende fandt sted. Ligeledes blev samtlige ansatte fra de afdelinger, der indgik i feltarbejde inviteret til adskillige møder, hvor formål, metode, varighed, sikkerhed og ansvar for processen blev gennemgået og diskuteret.

Feltarbejdet blev afviklet i tre forskellige faser (se tabel 1), i afdelinger med en variation i rapportering af oplevet mobning. I analysen trækkes der på situationer på tværs af feltarbejdets faser og forskellige enheder. Kulturelle praksisser bliver til gennem dynamiske fletværk af forbindelser mellem kulturelle markører og kollektive betydningsdannelser i såvel sociale som geometriske rum. Formålet med analysen er således ikke at sammenligne på tværs af enhederne, men er i stedet drevet frem af et ønske om at belyse og forstå dynamikker og forbindelser mellem markører og betydningsdannelser, der gør muliggør at mobning kan opstå.

\section{Tabel 1: Feltarbejdet}

\begin{tabular}{lll} 
Sted & Varighed & Formål \\
\hline Sengeafsnit & $\begin{array}{l}\text { 6 uger; dag-, nat- og } \\
\text { weekendvagter }\end{array}$ & $\begin{array}{l}\text { Arbejdsgange og samarbejde mellem } \\
\text { læger og sygeplejersker }\end{array}$ \\
\hline Operationsgang & $\begin{array}{l}\text { 6 uger; dag-, nat- og } \\
\text { weekendvagter }\end{array}$ & $\begin{array}{l}\text { Arbejdsgange og samarbejde mellem } \\
\text { læger og sygeplejersker }\end{array}$ \\
\hline $\begin{array}{l}\text { Følge en gruppe } \\
\text { af kirurger }\end{array}$ & $\begin{array}{l}6 \text { uger; dag-, nat- og } \\
\text { weekendvagter }\end{array}$ & $\begin{array}{l}\text { Kirurgers daglige arbejdspraksis og } \\
\text { arbejdsvilkår }\end{array}$ \\
\hline
\end{tabular}


Umiddelbart efter feltarbejdet blev to fokusgruppediskussioner med 5 anæstesisygeplejersker, tre kvalitative enkeltinterviews med operationssygeplejersker og 3 kvalitative enkeltinterview med kirurger gennemført. Alle deltagere i fokusgruppediskussionerne og enkeltinterviewene var personale, der ligeledes havde deltaget i feltarbejdets deltagende observationer. Alle fokusgruppediskussionerne og enkeltinterviewene blev optaget på diktafon og efterfølgende transskriberet ordret efter samme på forhånd definerede transskriptionsnøgle.

Det følgende udgør en analyse, som i overvejende grad har været induktivt og eksplorativt drevet, og som undervejs er blevet bragt i samspil med teoretiske begreber og overvejelser, vi anså for at kunne åbne op for belysning og forståelse af de empiriske fænomener. På denne måde har analysen udfoldet sig som en abduktiv proces (Brinkmann, 2014), hvor vi er 'snublet' (ibid.) over de kulturelle markører og de forbindelser, der emergerer gennem analyse- og kodningsarbejdet og som analyseres med det teoretiske blik. De teoretiske begreber som er fundet relevante undervejs, er blevet fremstillet i første del af artiklen. Nedenfor bringes de i spil i en analytisk vekselvirkning mellem det empiriske og det teoretiske. Opmærksomheden på arbejdspladskulturens særlige betydning for mobning er således vokset frem undervejs.

\section{Analyse: Mobnings kulturelle indlejring - når krænkelser bliver et inklusionskrav for fællesskabet}

I analysen fremføres først en indføring i etnografens rejse ind i arbejdsfællesskabet og dermed hendes læreproces i forhold til at kunne aflæse og sidenhen praktisere centrale kulturelle markører i bestræbelse på at opnå inklusion. En central betydningsbærende kulturel markør viste sig at være kompetencen til at 'tåle mosten', der henviser til en sarkastisk, ironisk, undertiden nedladende og endelig en seksualiseret omgangsform. Denne kulturelt selvfølgelige omgangsform skaber grobund for indlejret flertydighed og erfaret ambivalens. Det skal forstås således, at socio-kulturelle vilkår i arbejdet danner grobund for, at læger og sygeplejersker opfatter en omgangsform, som er potentiel sundhedsskadelig (Einarsen \& Nielsen, 2014; Hansen et al., 2006; Reknes et al., 2014), for passende og legitim. Når nogle ansatte undertiden oplever det tilsyneladende passende som upassende, bliver det vanskeligt for dem at sige fra, fordi de dermed risikerer at blive ekskluderet. Dette er en medvirkende drivkraft for nogle af de arbejdspladskulturelle læreprocesser, der fører til mobning, vi skal se nærmere på i analysen nedenfor.

\section{Velkommen til en af foellesskabets centrale kulturelle markører - 'den hårde tone'}

"Nu må vi se om hun kan klare mosten, ha ha ha... Om hun kan klare den hårde tone vi har her, ha ha ha...". Det er min forste dag på feltarbejde. Sygeplejerskerne på afdelingen har kollektivt besluttet, at jeg skal følges med den sygeplejerske i afdelingen, der passer den patient som har det største post-operative sår. Bare lige for at se om jeg kan klare presset. Med smørrede grin om munden forklarer hun og et par andre sygeplejersker mig, hvad jeg skal gøre, hvis jeg nu får et ildebefindende inde ved patienten: "Hvis du bliver utilpas, saetter du dig ned på gulvet med ryggen mod voeggen og hoved ned mellem benene, så du ikke falder ind over patienten, ik? ha ha ha..." instruerer de mig storgrinende. Jeg smiler bekraeftende tilbage til dem. Jeg har forberedt mig på mit feltarbejde ved at se operationer på fjernsyn. "Du kan ikke forberede dig på det, du kommer til at opleve herinde." fortoeller en afdelingssygeplejerske mig. "Det er ligesom at føde børn; 
du kan gå til fødselsforberedelse, men virkeligheden overgår din vildeste fantasi." siger hun med et stort smil." (Feltnote)

Allerede første dag på feltarbejdet blev etnografen præsenteret for det, der skulle vise sig at blive omtalt mange gange sidenhen som 'den hårde tone'. I ovenstående situation er det en gruppe sygeplejersker, der sætter ord på deres tanker om, hvorvidt forskeren kan 'tåle mosten' og klare 'den hårde tone'. De fagprofessionelle byder hermed etnografen velkommen ved at invitere hende ind $i$ den kulturelt passende omgangsform, der betragtes som gængs og selvfølgelig. Med deres indlejrede kulturelt meningsfulde forbindelser mellem en hård tone og arbejdet på et sengeafsnit på et hospital, kærer de sig om etnografen ved at forsøge at lære hende at møde deres virkelighed med den hårdhed, som de anser for at være nødvendig for overlevelse i hospitalsarbejde. Læreprocessen henimod hårdhed faciliteres via latterliggørende humoristiske instrukser, hvor tvivl, usikkerhed og sårbarhed udgrænses, og mestring af vanskelige situationer overlades til den enkelte.

\section{'Den hårde tones' indlejrede ambivalens}

I andre praksisser er det læger, der omtaler 'den hårde tone'. Og andre gange igen er det personale, der omtaler andre personalegrupper som ansatte, der bør 'opdrages' på i forhold til 'den hårde tone':

\footnotetext{
"Jeg er inviteret med til personalets julefrokost og direktøren holder tale. Han roser alle medarbejdere for deres arbejdsmoessige indsats ved at fortoelle om den forskel de hver isaer gør for centrets samlede virke. Da han kommer til mig omtaler han mig som "centrets egen lille muldvarpe". Han positionerer mig sprogligt som en udsendt spion, 'under cover', der har til opgave at infiltrere systemet og kulturen
}

indefra. Det oplever han tilsyneladende, at der er behov for, fordi der hersker "en hård tone". De andre medarbejdere griner, mens han fortoeller det. Under den efterfølgende middag spørger en stabsmedarbejder mig om, hvorvidt jeg opdager noget spoendende om loegerne og om jeg får loert dem en ting eller to om god opførsel. "Er du lykkedes med at opdrage lidt på dem?" spørger han grinende." (Feltnote)

I processen fra at være kulturel novice til at blive en accepteret del af fællesskabet, opstår en kulturel selvfølgeliggørelse af det, som fra et udefrakommende perspektiv, kan forekomme forbløffende og snublende (Brinkmann, 2014). 'Den hårde tone' omtales her (indirekte) som noget problematisk og uhensigtsmæssigt af direktøren og stabsmedarbejderen samtidig med, at emnet danner grundlag for morskab og latter. Mortensen \& Mygind du Plessis (2019) viser i deres artikel, hvordan den nedgørende humor bl.a. tjener en ventileringsfunktion, der har til formål, at give personalet mulighed for at få afløb for frustration gennem humor, der betragtes som mere passende og dermed kulturel acceptabel end en direkte konfrontation.

"Muldvarpe" anvendes undertiden i overført betydning til at beskrive en "Person som tilsyneladende arbejder loyalt for en organisation el.lign., men som $i$ hemmelighed spionerer og prøver at skade organisationen indefra." (Den Danske Ordbog, 2020). Imidlertid vidste alle ansatte i de afdelinger, hvor feltarbejdet fandt sted, forud for deltagerobservationen, hvem etnografen var samt formålet med hendes tilstedeværelse, nemlig at generere forskningsbaseret viden om hvad, der kan have betydning for dysfunktionelle samarbejdsrelationer, herunder evt. krænkende handlinger og/eller mobning. Forskerens ærinde var ingen hemmelighed og etnografen havde ikke til hensigt at skade organisationen (hvilket ledelsen vidste), men derimod at forsøge at lære om organisationen og forstå dens 
virke. Alligevel omtalte direktøren etnografen som "centrets egen lille muldvarpe (...) der har til opgave at infiltrere systemet og kulturen indefra." Således udpeges 'den hårde tone' socialt i ovenstående eksempel både som uhensigtsmæssig samtidig med, at de ansatte distancerer sig til den ved brug af humor. Denne ambivalens i forhold til 'den hårde tone' praktiserede de ansatte vedvarende i forskellige kontekster under hele feltarbejdet. Som det fremgår af næste feltnote italesatte de ansatte undertiden også denne ambivalens.

\section{Kulturel positionering; faglig omnipotent og dedikeret mester}

"En portør som netop har hiulpet med at omlejre en patient kommer tilbage til operationsstuen, fordi han er optaget af, hvad han skal gøre med sine traesko. "Hvor skal jeg stille dem? Hvordan bliver de vasket?" spørger han. Undervejs holder han toenkepauser og siger højt til sig selv, at han lige skal have styr på tankerne. Da han har forladt operationsstuen griner alle tilbagevaerende. "Han er vist "tung i arbejde." siger en sygeplejerske. Nogle andre svarer, at han blot er nyuddannet. "Dér var da én som kunne bruge din hjoelp" siger loegen som sidder ved siden af mig. "Synes du vi er grove?" spørger en anden sygeplejerske mig. Jeg svarer, at jeg ikke har til formål at vurdere nogen. "Vi har en hård tone." afslutter hun. "Han var da i hvert fald dum... og tyk..." konkluderer loege Susanne. "Det må du da ikke sige. Det er tabu." svarer laege Torben og smiler til hende. "Nå", siger Susanne. "Så er han cerebralt udfordret." tilføjer hun. Alle griner. (Feltnote)

En nyansat har per definition meget at lære og kan derfor ikke umiddelbart bidrage til arbejdsopgaverne på samme niveau som de mere erfarne ansatte. I et accelereret arbejds- liv, der indebærer et stort ansvar for andre menneskers liv, tolereres fejl, inkompetence og uvidenhed dårligt, fordi såvel sundhedspersonalet selv som omverdenen har brug for at opretholde et billede af læger og sygeplejersker som omnipotente (Mortensen \& Mygind du Plessis, 2019). En overlæge udtrykker det således:

"Vi synes selv vi er så dedikerede til vores fag, at dem der ligesom kommer ind på det her hold, skal vide at vores opfattelse er, at hvis du skal proestere på det her niveau, så skal det voere - ikke dit liv, men noesten dit liv, det her." (Interview)

Lægen argumenterer her for en kulturel (selvfølgelig) forbindelse mellem arbejdsliv og livet: Hvis ikke arbejdsliv er det vigtigste i livet, så bør det være (meget) tæt på at være det vigtigste i livet. Den meningsfulde og socialt acceptable faglige position som udpeges her, bl.a. gennem latterliggørende drillerier af portøren, er at udvise dedikeret adfærd i arbejdet, hvorved det at være fejlbarlig, uvidende, uengageret og illoyal over for 'faget' udgrænses som kulturelt upassende. For at opnå accept og inklusion i arbejdsfællesskabet må den ansatte kunne genkendes sociokulturelt som dedikeret ved at kunne præstere på højeste niveau. Det er vigtigt at understrege, at kulturelle læreprocesser ikke er lineære, hvor det er givet, at kulturelle novicer er perifere og erfarne partout er kulturelle mestrer. Positionerne er flydende og kan ændres (hurtigt) over tid. Faglige kulturelle selvfølgelige praksisser kan fx omkalfatres ved indførelse af ny teknologi, ændringer i patientgruppe, ledelsesskift med videre. På samme måde kan kulturelt meningsfulde forbindelser for jargon og tone udfordres. Kulturelt og fagligt erfarne ansatte kan således pludselig opleve et tab af sociokulturel status i arbejdsfællesskabet. 


\section{Kropsliggjort handleviden; mobning som selvfølgeliggjort praksis}

Under feltarbejdets interviews spurgte etnografen ligeledes til personalets oplevelse af 'den hårde tone' ved at gengive eksempler fra feltarbejdet, der ligesom eksemplet ovenfor omhandler 'den hårde tone'. Den kulturelle forbindelse, som gentagende gange kodes som meningsfuld under interviewene, er et historisk perspektiv, der fordrer en bestemt omgangsform. En læge udtaler:

"Jaa, men det er jo noget historisk noget ('den hårde tone', red.), som formentlig er startet laenge før, vi er startet. (...) Det kan da godt irritere én nogle gange, men du har vaeret tilpas loenge i det her system, så er det jo ikke noget, man tager sig noert som sådan altså, så ved man, at de bemaerkninger, de kommer også. Og så kan man jo blive sur over dem, eller man kan sige "nå" til dem, eller man kan bare selv ironisere over dem, for at komme ud af det på en eller anden måde. Det har vi taget med os, og så er der nogen, der ikke bryder sig om tonen. (...) Og så tror jeg måske ikke... Hvis man skal loegge så meget $i$ det, altså jeg tror..." (Interview)

Lægen koder mobningen ('den hårde tone') kulturelt - som et spørgsmål om tilvænning. Han rejser ikke spørgsmålet om, hvorvidt det kunne være en mulighed at ændre den "irriterende" omgangstone og dermed måske bringe den krænkende adfærd til ophør. Han beskriver i stedet mobningen som en kulturel læreproces, hvor den enkelte lærer at udvikle overlevelsesstrategier, hvis han/hun "har voeret tilpas loenge $i$ det her system. Hvis den enkelte har lært at afkode 'den hårde tones' kulturelle markører, "ved man, at det kommer", og så kan man gøre sig hård ved at sige "nå" eller selv ironisere. Det er de mulighedsrum, som det lokale tankeredskab stiller til rådighed. Det forstærker et kulturelt fællesskab, hvor risiko for krænkende handlinger og/eller mobning øges. Oprør mod 'den hårde tone' ekskluderes dermed som en meningsfuld mulig adfærd i det sociale rum, som lægen er medskaber af. For ham bliver det i stedet meningsfuldt at finde veje til at kunne leve med mobningen - ikke at finde veje til at stoppe den. Som vi skal se senere, er han ikke alene om denne betydnings- og meningstilskrivning.

\section{Kulturel loering gennem social udpegning og genkendelse}

At lære om kulturelle markøres relevante forbindelser, og dermed socialt bestemt relevant betydning og mening i (sprog) handlinger, foregår ofte tavst og kropsligt i en kontinuerlig bestræbelse efter at blive socialt udpeget og genkendt med håb om accept og dermed inklusion i arbejdsfællesskabet. En læge udtaler:

"Det er ikke sådan, at vi bevidst siger, "nu skal vi have en hård tone (...) Men hvis du ligesom er opdraget $i$ det, så... hvis du som kirurg er opdraget, da du kom ind i faget, der blev du proeget af dine omgivelser, ikke? De aeldre kolleger, du møder første gang, hvis de har den tone, så skroemmer det dig vaek, og så skal du ikke have noget med det at gøre. Eller også siger du "nå ok, det kan jeg sku godt deale med, det synes jeg sådan set er ok". Og så bliver du jo farvet af det $i$ din egen opforsel, tror jeg, langt hen ad vejen. Først på et sent tidspunkt toenker du "ah, måske skulle man modificere det lidt" ikke?" (Interview)

Lægen beskriver her, hvordan kulturelt acceptable forbindelser, tillæres - i dette tilfælde, at kunne 'tåle mosten' - gennem social udpegning fra "de oeldre kolleger". En central del af den sociale udpegning og genkendelse omhandler det at kunne 'tåle mosten' og 'den hårde tone'. Og så må den enkelte tage 
stilling til, om han/hun kan "deale" med mobningen eller i stedet vælge at gå ind i et andet fag og dermed forlade jobbet som læge eller sygeplejerske. Det nytter ikke "at have en rygrad som en vandslange" som en sygeplejerske formulerede det under feltarbejdet. Til spørgsmålet om, hvorvidt omgangsformen udelukkende knytter sig til arbejdet på en operationsgang, svarer en læge:

"Det er jo også gået op for mig, at andre er jo også nogle banditter, $i$ en anden forkloedning. Altså de er det bare på en anden måde. Medicinere er også nogle banditter. De er det bare mere poleret. Altså, forstår du, hvad jeg mener? Man kan voere bandit på mange måder, ikke? Vores er sådan. Den historie, vi har er måske meget simpel bandit - lige ud ad landevejen. Sorteper, man kan sige det og... Det er meget... hvor andre har sådan mere subtil måde at voere banditter på, hvis du kommer ud på en medicinsk afdeling. Der er det mere intellektuelt-agtigt. Men det kan voere fuldstoendigt lige så giftige, som vi kan. Det har jeg da opdaget." (Interview)

Lægen argumenterer her for, at den kulturelle forbindelse imellem det at være hospitalsansat og samtidig at være "en bandit", ikke kun gælder for ansatte på en operationsgang, men ligeledes ansatte på medicinske afdelinger. Den sociale udpegning er dog anderledes for ansatte i det medicinske område, ved at mobningen i sidstnævnte kontekst omtales som værende "mere poleret og subtil forkloedt".

\section{Da etnografen blev socialt udpeget som voerdig til inklusion}

I arbejdsfællesskaberne kodes krænkende handlinger og mobning kulturelt som et historisk uforanderligt grundvilkår i hospitalsarbejde, som den enkelte ansatte enten må lære at praktisere for at opnå inklusion eller kan vælge at forlade og dermed blive ekskluderet. At kunne 'tåle mosten' og 'den hårde tone' bliver hermed en central grundlæggende kulturel meningsfuld forbindelse i det sociale rum de ansatte navigerer arbejdsmæssigt i. Samtidig bliver dét at mestre mobning en vigtig kulturel praksis for at opnå social genkendelse og dermed øge chancen for inklusion:

"Jeg møder ind i dagvagt og er forkølet, hoster og pudser noese. Overloege Bjarke, som jeg skal følges med den dag, spørger mig, om jeg ikke skal hjem og pleje min sygdom. Jeg svarer, at jeg ikke er syg, men blot forkølet. Da han nogle gange har noevnt, at jeg bør tage hjem, svarer jeg, at jeg godt ved, at vi kvinder foder børn, men når maend er forkølet, tror de, at de skal dø. Bjarke slår en høj latter op, kigger på mig og siger så "Mille, du skulle ikke have voeret psykolog, du skulle have voeret kirurg."” (Feltnoter)

I ovenstående situation nedgør etnografen mænd for en påstået manglende hårdhed i forhold til sygdom og smerte ved at fortælle lægen, at kvinder kan føde børn, og at mænd ikke kan tåle at blive forkølede. Den nedgørelse af mænd, som hendes kommentar indeholder, udløser ikke blot latter hos den mandlige læge, men også en social og kulturel genkendelse og anerkendelse af etnografen ved at lægen vurderer, at hun med sin kulturelle mestring af krænkende adfærd gennem kommentaren, kunne være kirurg. Han viser hermed, at forbindelsen mellem en nedgørende og dermed krænkende kommentar (omend den er pakket ind i humor) og virket som kirurg for ham er en kulturel meningsfuld forbindelse. Derfor genkender han sin profession i etnografens sproglige praksis, hvorved hun øger sine chancer for at blive inkluderet i det sociale rum på arbejdspladsen. Dagen efter denne ordveksling mellem etnografen og lægen giver selvsamme læge etnografen lov til at gå i sterilt til operationen og assistere lægen 
ved operationsfeltet - det vigtigste og mest betydningsfulde faglige og materielle rum under en operation. Det kan være et tilfælde, men vi vil argumentere for, at det ikke er.

Det er værd at bemærke, at etnografen, i selve situationen, ikke havde blik for sin egen udøvelse af en, for lægen, relevant kulturel praksis. Det udfoldede sig blot. I sin læreproces havde hun, næsten uden at være opmærksom herpå, kropsligt indlejret denne kulturelt acceptable adfærd, der tillod hende adgang til en højagtet faglig praksis. Det var først i de senere genlæsninger af feltnoterne og analysefaser, at hendes kulturelle læreproces stod tydeligt frem.

Forskning (Einarsen et al., 2011) og dansk lovgivning (Arbejdstilsynet, 2019) definerer det, der af de ansatte omtales som 'den hårde tone', som krænkende handlinger, der med sin kontinuitet og varighed kan defineres som mobning (Mortensen \& Baarts, 2018), og derfor udgør en sundhedsmæssig risiko for de ansatte (Einarsen \& Nielsen, 2014; Reknes et al., 2014).

Desuagtet benævner deltagerne i interviewene ikke selv situationerne som 'mobning' eller 'krænkende handlinger'. De taler om noget, der "irriterer", er "giftigt" og er "bandit"-agtigt. Undertiden appelleres implicit til etnografen om at afsløre skyggesiderne af kulturen ("muldvarpen"), og til at hjælpe med at skabe et bedre arbejdsmiljø ("Er du lykkes med at opdrage lidt på dem", "loere kirurgerne noget om arbejdsmiljø"), men appellerne er, når de udfoldes i kontekst af fællesskabets kulturelle markører, pakket ind i sarkasme og ironi, og kommer dermed paradoksalt nok til at reproducere og konsolidere selvsamme kulturelle markører.

\section{Konklusion - mobning som kulturelle læreprocesser}

Formålet med artiklen har været at undersøge, hvilken rolle arbejdspladskultur spiller for tilblivelsen af mobning på arbejdspladsen ved at skabe indsigt i, hvordan in- og eksklusionsmekanismer, der danner grundlag for mobning, er indlejret i kulturelle praksisser.

Et etnografisk studie blandt hospitalsansatte giver en dybere forståelse af mobningens indlejring i kulturelle praksisser ved at vise, hvordan de ansatte i konkrete handlinger skaber og vedligeholder praksisser, der lærer deltagere at udføre krænkende handlinger og mobning. Dette kommer også til udtryk gennem etnografens egen kulturelle læringsproces, hvor mestring af fællesskabets kulturelle markører i en konkret situation er afgørende for, at etnografen vurderes som værdigt medlem og inkluderes gennem social udpegning og genkendelse af fællesskabets mere erfarne kulturelle medlemmer.

Studiet viser, at hvis mobning udgør en betydningsfuld kulturel markør i arbejdsfællesskabet, må potentielle medlemmer blandt hospitalsansatte være villige til at krænke kolleger og lade sig udsætte for krænkende handlinger af kolleger for at opnå inklusion og udføre deres arbejdsopgaver. I den konkrete kulturelle praksis er en væsentlig kulturel betydningsforbindelse dét at kunne 'tåle mosten' og 'den hårde tone'. Det er indlejret i kulturen og betragtes i konteksten som et grundvilkår i hospitalsarbejdet.

Artiklen præsenterer en alternativ tilgang til mobning, hvor krænkende handlinger og mobning ikke forårsages af dysfunktionelle personligheder, men bliver til som et led i kulturelle læreprocesser på vejen fra kulturel novice til kulturel erfarent medlem af arbejdsfællesskabet.

Når etnografen i studiet præsenterer de hospitalsansatte for konkrete situationer, fra deres egen hverdagspraksis, som indeholder krænkelser, genkender de dem ikke som 'mobning' eller 'krænkende handlinger'. Det understøtter, at denne handleviden er indlejret og selvfølgeliggjort i de kulturelle praksisser. Men, flere ansatte appellerer sam- 
tidig indirekte til etnografen om at afsløre skyggesiderne af kulturen og om at hjælpe med at skabe et bedre arbejdsmiljø. Disse udtrykte ambivalenser og flertydigheder i handlinger kan betragtes som mulige sprækker eller åbninger til at gøre noget andet.

\section{Nye handlerum for strategier om mobning}

En arbejdspladskulturel tilgang til mobning muliggør nye handlerum for forebyggelse og håndteringsstrategier om mobning ved at betragte kultur som midlertidige kulturelt selvfølgelige praksisser, der løbende transformeres via friktioner.

Friktioner kan gøre ansatte opmærksomme på kulturelle selvfølgeligheder, der praktiseres som en tavs, kropslig og automatiseret adfærd. Organisationsforandringer kan fx transformere de kulturelle praksisser, men det er også en mulighed at præsentere nye mulige forbindelser i relationerne mellem handling og betydning på andre måder. Det kan ske gennem interventioner, $\mathrm{fx}$ ved at gøre eller sige noget andet, end fællesskabet plejer at gøre. Det skaber friktion, der gør, at vi pludselig bliver bevidste om noget, der har været taget for givet. Friktioner kan i denne sammenhæng være at præsentere deltagere i fællesskabet, både de kulturelt erfarne og nye, for nye tolkninger af handlinger, ord og genstande gennem alternative mulige kulturelle forbindelser og praksisser end de eksisterende. På den måde vil der kunne åbnes op for nye kulturelle modeller, der kodes med nye selvfølgelige tolkninger af handlinger, ord og genstande, der ikke har karakter af krænkende handlinger og mobning.

Med andre ord er 'en hård tone' og det at kunne 'klare mosten' ikke et uforanderligt grundvilkår i hospitalsarbejde, men derimod en selvproduceret og selvforhandlet kulturel praksis og meningstilskrivning, der kan undersøges og udvikles med andre kulturelle meningstilskrivninger og praksisser end mobning og samtidig hjælpe de ansatte med at navigere i et arbejdsliv på kanten af liv og død.

\section{ReferenCeR}

An, Y. \& Kang, J. (2016). Relationship between Organizational Culture and Workplace Bullying among Korean Nurses. Asian Nursing Research, 10(3), 234-239. doi: 10.1016/j.anr.2016.06.004

Arbejdstilsynet (2019). At-vejledning 4.3.1, Krænkende handlinger, herunder mobning og seksuel chikane https://at.dk/regler/at-vejledninger/kraenkende-handlinger-4-3-1/

Bateson, G. (1972). Steps to an Ecology of Mind: Collected Essays in Anthropology, Psychiatry, Evolution, and Epistemology, 2000th ed. Chicago: University of Chicago Press.

Bloch, C. (2012). How do perpetrators experience bullying at the workplace? International Journal of Work Organization and Emotion, 5(2), 159-177. doi:10.1504/IJWOE.2012.049519

Bloisi, W. \& Hoel, H. (2008). Abusive work practices and bullying among chefs: A review of the literature. International Journal of Hospitality Management, 27(4), 649-656. doi: 10.1016/j. ijhm.2007.09.001

Brinkmann, S. (2014). Doing Without Data. Qualitative Inquiry, 20(6), 720-725. doi:10.1177/1077800414530254

Cole, M. (1996). Cultural psychology: A once and future discipline. Massachusetts: Harvard University Press.

D'Cruz, P. (2015). Depersonalized Bullying at Work From Evidence to Conceptualization, Springer Briefs in Psychology. London: Springer India.

D'Cruz, P. \& Noronha, E. (2013). Breathers, Releases, Outlets and Pauses: Employee Resistance 
in the Context of Depersonalized Bullying. Qualitative Report, 18, 1-24.

Det Nationale Forskningscenter for Arbejdsmiljø (2018). Arbejdsmiljø og Helbred i Danmark. Det Nationale Forskningscenter for Arbejdsmiljø.

Dewey, J. (1916/1966). Democracy and Education. An introduction to the Philosophy of Education. New York: The Free Press.

Einarsen, S. \& Mikkelsen, E. (2000). Mobning i arbejdslivet: Hvad er det og hvad ved vi om det?. Tidsskrift for Arbejdsliv, 2(1), 7. doi:10.7146/tfa.v2i1.108299

Einarsen, S., Hoel, H., Zapf, D. \& Cooper, C. (2011). Bullying and Harassment in the Workplace: Developments. I Theory, Research, and Practice (2nd ed.). New York: CRC Press.

Einarsen, S. \& Nielsen, M. B. (2014). Workplace bullying as an antecedent of mental health problems: a five-year prospective and representative study. International. Archives of Occupational Environmental. Health, 88(2), 131-142. doi:10.1007/s00420-014-0944-7

Einarsen, S. \& Raknes, B. (1997). Harassment in the workplace and the victimization of men. Violence and Victims, 12(3), 247-263. doi: 10.1891/0886-6708.12.3.247

Fox, S. \& Freeman, A. (2011). Narcissism and the Deviant Citizen: A Common Thread in CWB and OCB. I P. L. Perrewé, \& D. C Ganster (red.), The Role of Individual Differences in Occupational Stress and Well Being (s. 151-196). Bingley. UK: Emerald.

Geertz, C. (1973). The Interpretation Of Cultures. London: Fontana Press.

Gherardi, S. (2000). Practice-Based Theorizing on Learning and Knowing in Organizations. Organization, 7(2), 211-223. doi:10.1177/135050840072001

Hansen, Å., Hogh, A., Persson, R., Karlson, B., Garde, A. \& Ørbæk, P. (2006). Bullying at work, health outcomes, and physiological stress response. Journal of Psychosomatic Research, 60(1), 63-72. doi:10.1016/j.jpsychores.2005.06.078

Hasse, C. (2011). Kulturanalyse i organisationer. Frederiksberg: Samfundslitteratur.

Hastrup, K. (2003). Ind i verden - Introduktion. I K. Hastrup (red.), Ind $i$ Verden: En Grundbog i Antropologisk Metode (s. 9-33). København: Hans Reitzels Forlag.

Hoel, H., Giga, S. I. \& Davidson, M. J. (2007). Expectations and realities of student nurses' experiences of negative behaviour and bullying in clinical placement and the influences of socialization processes. Health Services Management Research, 20(4), 270-278. doi: $10.1258 / 095148407782219049$

Jackson, J. E. (1990). "I Am a Fieldnote": Fieldnotes as a Symbol of Professional Identity. I Sanjek, R. (red.), Fieldnotes: The Makings of Anthropology (s. 3-33). London: Cornell University Press.

Keashly, L. \& Jagatic, K. (2011). North American perspectives on hostile behaviors and bullying at work. Bullying and harassment in the workplace: Developments in theory, research, and practice, 2, 41-71.

Kofoed, J. \& Søndergaard, D. M. (red.), (2009). Mobning - Sociale processer på afveje. København: Hans Reitzels Forlag.

Lave, J. \& Wenger, E. (1991). Situated learning: Legitimate peripheral participation. Cambridge: Cambridge University Press.

Liefooghe, A. \& Mac Davey, K. (2001). Accounts of workplace bullying: The role of the organization. European Journal of Work and Organizational Psychology, 10(4), 375-392. doi:10.1080/13594320143000762

Linton, D. K. \& Power, J. L. (2013). The personality traits of workplace bullies are often shared by their victims: Is there a dark side to victims? Personality and Individual Difference, 54(6), 738-743. doi:10.1016/j.paid.2012.11.026

Mathisen, G., Einarsen, S. \& Mykletun, R. (2011). The Relationship Between Supervisor Personality, Supervisors' Perceived Stress and Workplace Bullying. Journal of Business Ethics, 99(4), 637-651. doi:10.1007/s10551-010-0674-Z

Mikkelsen, E. G., Hogh, A. \& Puggaard, L. B. (2011). Prevention of bullying and conflicts at work: Process factors influencing the implementation and effects of interventions. International Journal of Workplace Health Management, 4(1), 84-100. doi:10.1108/17538351111118617

Mortensen, M. \& Baarts, C. A. (2018). Killing ourselves with laughter ... mapping the interplay of organizational teasing and workplace 
bullying in hospital work life. Qualitative Research in Organizations and Management: An International Journal, 13(1), 10-31. doi:10.1108/ QROM-10-2016-1429

Mortensen, M. \& Mygind du Plessis, E. (2019). Mobning som (mod)magt - En Foucauldiansk analyse af humoristiske krænkende handlinger i hospitalsarbejde. Dansk Sociologi, 3(30), 7-33. Pheko, M., Monteiro, N. \& Segopolo, M. (2017). When work hurts: A conceptual framework explaining how organizational culture may perpetuate workplace bullying. Journal of Human Behavior in the Social Environment, 27(6), 571-588. doi:10.1080/10911359.2017 .1300973

Pilch, I. \& Turska, E. (2015). Relationships Between Machiavellianism, Organizational Culture, and Workplace Bullying: Emotional Abuse from the Target's and the Perpetrator's Perspective. Journal of Business Ethics, 128(1), 83-93. doi:10.1007/s10551-014-2081-3

Reknes, I., Pallesen, S., Magerøy, N., Moen, B. E., Bjorvatn, B. \& Einarsen, S., (2014). Exposure to bullying behaviors as a predictor of mental health problems among Norwegian nurses: Results from the prospective SUSSH-survey. International Journal of Nursing Studies, 51(3), 479-487. doi:10.1016/j.ijnurstu.2013.06.017

Schein, E. H. (1984). Coming to a New Awareness of Organizational Culture. Sloan Management Review, 25(2), 3-16.

Schott, R. M. (2009). Mobning som socialt begreb: Filosofiske refleksioner over definitioner. I J. KofoedSøndergaard, D.M. (red.) Mobning Sociale processer på afveje. København: Hans Reitzels Forlag

Schultz, M. (1990). Kultur i organisationer: Funktion eller symbol. København: Handelshøjskolens forlag.

Trépanier, S.-G., Fernet, C., Austin, S. \& Boudrias, V. (2016). Work environment antecedents of bullying: A review and integrative model applied to registered nurses. International Journal of Nursing Studies., 55, 85-97. doi:10.1016/j. ijnurstu. 2015

Vygotskii, L. \& Cole, M. (1978). Mind in society: the development of higher psychological processes . Cambridge: Harvard University Press.

Mille Mortensen, ph.d. studerende, konsulent Institut for Psykologi, Københavns Universitet e-mail: mille.mortensen@psy.ku.dk

Peter Hagedorn-Rasmussen, lektor, ph.d. Institut for Mennesker og Teknologi, Roskilde Universitet e-mail: peterhag@ruc.dk

Rikke Thomsen, konsulent, ph.d. Tilknyttet Institut for Mennesker og Teknologi, Roskilde Universitet e-mail: thomsenrikke@hotmail.com 